\title{
Website Libel and the Single Publication Rule
}

\author{
Sapna Kumar†
}

The single publication rule was created to compensate libel victims for reputational harm without crippling the publishing industry. During the nineteenth century, American courts followed the multiple publication rule. ${ }^{1}$ In 1849 an English court established this rule, ${ }^{2}$ which states that each delivery of a libelous statement to a third party constitutes a new publication of the libel, which in turn gives rise to a new cause of action. ${ }^{3}$

As mass publishing became more common during the twentieth century, courts faced a dilemma. The multiple publication rule was adopted when communities were small and circulation of printed materials was limited, thus inherently limiting the burden that publishers accused of libel could face. But with technological breakthroughs such as the modern printing press, a single libelous statement could now reach millions of readers and lead to a staggering number of lawsuits. Courts became concerned that the statute of limitations would no longer be effective if it were renewed every time a new party saw the libelous statement. ${ }^{6}$ A rule was needed that would give libel victims adequate means to seek redress without forcing publishers to face countless lawsuits for an indefinite span of time. Consequently, courts began to adopt the single publication rule. Under this rule, a libel victim would have only one cause of action for the mass or aggregate

$\dagger$ B.S., B.A. 1999, University of Texas; J.D. Candidate 2003, The University of Chicago.

1 See, for example, Staub v Van Benthuysen, 36 La Ann 467, 469 (1884) ("Every sale or delivery of a written or printed copy of a libel is a fresh publication, and every person who sells a written or printed copy of it may be sued therefor[e].").

2 See Duke of Brunswick and Luneberg v Harmer, 14 QB 185,188-89 (1849) (permitting a cause of action for each copy of a newspaper that was printed with a libelous statement).

3 See Gregoire v GP Putnam's Sons, 298 NY 119, 81 NE2d 45, 47 (1948). See also Staub, 36 La Ann at 469; O'Reilly v Curtis Publishing Co, 31 F Supp 365, 365 (D Mass 1940).

4 See Bradford v American Media Operations, 882 F Supp 1508, 1513 (ED Penn 1995) (noting that the multiple publication rule may or may not have been appropriate at the time Duke of Brunswick was decided, given the small communities and limited circulation of newspapers).

5 See Fowler V. Harper, Fleming James, Jr., and Oscar S. Gray, 2 The Law of Torts $\$ 5.16$ at 126-27 (Little, Brown 2d ed 1986) (noting that the multiple publication rule has given rise to problems involving multiplicity of suits due to technological advances which have resulted in successive, and instantaneous publications).

6 See Gregoire, 81 NE2d at $48-49$ (applying the single publication rule to book publications to prevent dilution of the statute of limitations). 
publication of a libelous statement. ${ }^{7}$ This rule decreases the burden of publishers fighting off libel suits without diminishing the remedies available to the victim.

With the rise in popularity of the World Wide Web ("Web") ${ }^{8}$ over the past twelve years, courts are beginning to examine how to apply the single publication rule to website libel. Courts have agreed that website libel falls under the umbrella of the single publication rule because the Web is a form of mass publication. ${ }^{9}$ However, in implementing this rule, courts have skewed the single publication rule to favor publishers by broadly defining when publication on the Web occurs and narrowing the circumstances when republication can be found. As a result, courts have unnecessarily diminished the opportunity for libel victims to be compensated.

This Comment proposes new standards for finding initial publication and republication on the Web to maintain a balance between protecting libel victims and not hindering website publishing or the growth of the Web. Part I provides a broad introduction to libel law and discusses the scope of the single publication rule. It introduces the issue of website libel and discusses the three cases that have examined the issue. Part II examines some of the problems that arise from the current approach courts have taken in determining when initial publication and republication occur on the Web. Part III contends that initial publication should be found to occur when the intended audience of the libelous statement has a reasonable opportunity to discover it. Part III also argues that courts should find that a libelous statement

7 See generally Restatement (Second) of Torts § 577(A) (1977).

8 The World Wide Web, probably the most visible method of internet publication, refers to the set of computers ("servers") speaking certain communications protocols. A single server may host one or more websites - a loosely defined term referring to a related set of documents, usually with their own internet address. For example, nytimes.com is the website for The New York Times, and all the pages for this website have nytimes.com addresses. Websites consist of one or more pages, individual documents that may contain text, sound, pictures, video, or links to other pages. See Nancy J. Yeager and Robert E. McGrath, Web Server Technology: The Advanced Guide for World Wide Web Information Providers 1-4 (Morgan Kauffman 1996) (describing the unique features of and the technologies used by the Web).

Note that the internet itself is a set of computers that can talk to each other via the internet protocol. See Jon Postel, ed, Internet Protocol, RFC 0791 (1981), online at www.ietf.org/rfc/rfc0791.txt (visited Jan 29, 2003). The internet is not the same thing as the Web, despite the two terms being used interchangeably in common usage by the courts. See, for example, Firth $v$ New York, 706 NYS2d 835, 842 (Ct Cl 2000), affd 731 NYS2d 244 (App Div 2001), affd 98 NY2d 365, 775 NE2d 463 (2002) (stating that the issue at hand is whether the single publication rule applies to defamatory publications on the internet, when the entire case is concerned with only website publications). Not all servers are web-servers, and not all internetoperable devices are web-clients. This comment does not discuss other forms of internet publishing such as email, streaming audio, or USENET.

9 See notes 52-54 and accompanying text. 
has been republished when the statement itself is altered or when the website publisher knowingly attempts to disseminate the libelous statement to a new audience.

\section{The Single Publication Rule AND ITS AdAPTATION TO THE WORLD WIDE WEB}

This Part provides background on libel law and introduces the single publication rule. It then discusses how courts have applied the single publication doctrine to website libel and discusses some shortcomings in their analysis.

\section{A. An Introduction to Libel Law}

Defamation is the act of harming the reputation of another by making a false statement to a third party. ${ }^{10}$ The tort of libel is a subcategory of defamation that occurs when the defamatory statement in question is in writing or some other permanent medium," such as an electronic broadcast or a motion picture. ${ }^{12}$ Because the interest protected in defamation is reputational, the tort of defamation requires that the defamatory statement be communicated to someone other than the person defamed. ${ }^{13}$ The intentional communication of defamatory matter is known as a "publication.." ${ }^{14}$ The day that publication occurs is the "date of publication"; the statute of limitations begins to run from this date."

When compensating a libel victim, courts strongly prefer monetary damages to injunctive relief. In fact, the Supreme Court held in 1963 that "[a]ny system of prior restraints of expression comes to this Court bearing a heavy presumption against its constitutional valid-

10 See Black's Law Dictionary 427 (West 7th ed 1999). See also William L. Prosser, Handbook of The Law of Torts $\S 111$ at 737 (West 4th ed 1971) (noting that defamation is a "relational" interest because it involves the opinion that others have about the plaintiff and consequently, defamation requires that something be communicated to a third person that may affect this opinion).

11 This is in contrast to slander, which includes unfixed forms of expression such as speech. See Black's Law Dictionary at 1392 (cited in note 10).

12 See Prosser, Law of Torts $\S 112$ at 752 (cited in note 10) (noting libel is generally written, but has also been extended to include such categories as signs and motion pictures). See also Black's Law Dictionary at 927 (cited in note 10) ("A defamatory statement expressed in a fixed medium, esp. writing but also a picture, sign, or electronic broadcast.").

13 See Prosser, Law of Torts $\$ 113$ at 766 (cited in note 10).

14 See Restatement (Second) of Torts $\$ 577(1)$ ("Publication of defamatory matter is its communication intentionally or by a negligent act to one other than the person defamed.").

15 See Gregoire v GP Putnam's Sons, 298 NY 119, 81 NE2d 45, 47 (1948) (holding that a defamatory statement appearing in a single issue of a newspaper or magazine is in legal effect one publication giving rise to one cause of action, and that the applicable statute of limitations runs from the date of publication). 
ity." Consequently, courts generally hold that absent extraordinary circumstances, injunctions should not be issued against libelous speech. ${ }^{17}$ In other words, a libel victim must wait until the false statement harms her reputation and can then sue for damages before the statute of limitations expires. Ordinarily, the statute of limitations does not begin to run until harm to the victim's reputation has occurred. This Comment will show that under website libel caselaw, it is possible for the date of publication to occur before the victim's reputation is harmed, unnecessarily narrowing the window of time in which the victim can sue.

\section{B. The Single Publication Rule}

Most states follow the formulation of the single publication rule set forth in the Restatement (Second) of Torts. ${ }^{18}$ Section 577A(3) states that, "Any one edition of a book or newspaper, or any one radio or television broadcast, exhibition of a motion picture or similar aggregate communication is a single publication." ${ }^{19}$ Thus, under $\S 577 \mathrm{~A}(3)$, the publication of a libelous article in a magazine with a

16 Bantam Books, Inc v Sullivan, 372 US 58, 70 (1963) (holding that a Rhode Island commission's acts of censorship constituted a restraint on free expression in violation of the Fourteenth Amendment).

17 See Metro Opera Assn, Inc v Local 100, Hotel Empl \& Rest Empl Intl Union, 239 F3d 172,177 (2d Cir 2001) (vacating an injunction prohibiting defendant from making defamatory representations because injunctions are limited to rights that are without an adequate remedy at law, and libel may be remedied with damages); Kramer $v$ Thompson, 947 F2d 666, 679 (3d Cir 1991) (holding that under Pennsylvania law a court may not enjoin libelous speech because "equity should not intervene where legal remedies ... are adequate"); Community for Creative NonViolence v Pierce, 814 F2d 663,672 (DC Cir 1987) ("The usual rule is that equity does not enjoin a libel or slander and that the only remedy for defamation is an action for damages. However, under certain circumstances, declaratory and injunctive relief may be obtained against defamatory statements by government officials."); Kisser v Coalition for Religious Freedom, 1996 WL $147978, * 2$ (ND Ill 1996) (holding that under Illinois law "[p]rior restraints of speech will only be granted under exceptional circumstances. ... The general rule is that equity does not enjoin libel."); Kuang Hung Hu v Morgan, 405 F Supp 547, 548 (ED NC 1975) (referring to the common law rule that equity will not enjoin a crime such as libel under the common law, the court refuses to enjoin a defendant from threatening a witness because such action is already subject to criminal sanction by Congress); Hajek v Bill Mowbray Motors, Inc, 647 SW2d 253, 255 (Tex 1983) (dissolving an injunction against the defendant's defamation because "[d]efamation alone is not a sufficient justification for restraining an individual's right to speak freely"). But see Lothschuetz v Carpenter, 898 F2d 1200, 1206, 1208-09 (6th Cir 1990) (Wellford concurring in part, dissenting in part) (stating that under District of Columbia law a limited injunction against future libel may be granted to protect against future injury).

18 See Restatement (Second) of Torts $\$ 577$ A Reporter's Notes. See also Semida $v$ Rice, 863 F2d 1156, 1161 n 2 (4th Cir 1988); Givens v Quinn, 877 F Supp 485, 488 (WD Mo 1994); Foretich v Glamour, 753 F Supp 955, 960 (D DC 1990); Crook v Peacor, 579 F Supp 853, 856 (ED Mich 1984); Davis v Costa-Gavras, 580 F Supp 1082, 1093 (SD NY 1984).

19 Restatement (Second) of Torts $\S 577 \mathrm{~A}$. 
large circulation would count as a single publication and the libel victim would have only one cause of action against the publisher. ${ }^{20}$

The multiple publication rule still applies to libel that is not part of an aggregate or mass communication. ${ }^{21}$ In this case, each communication of the same libelous statement by the same libeler is a separate and distinct publication for which a separate cause of action arises. ${ }^{22}$ For example, if a person mails a libelous letter and five people read it, the victim will have five separate causes of action against the libeler. Montana and Wyoming continue to exclusively follow the multiple publication rule..$^{23}$ Fifteen states do not appear to have decided whether they follow the single publication rule. ${ }^{24}$

Seven states ${ }^{25}$ have adopted the single publication rule through the legislative enactment of the Uniform Single Publication Act (USPA). ${ }^{26}$ The USPA states:

No person shall have more than one cause of action for damages for libel ... founded upon any single publication or exhibition or utterance, such as any one edition of a newspaper or book or magazine or any one presentation to an audience or any one

20 See id $\S 577 \mathrm{~A}$, Illustrations of Comment on Subsection (3).

21 See id $\S 577(\mathrm{~A})(1)$ ("Except as stated in Subsections (2) and (3), each of several communications to a third person by the same defamer is a separate publication.").

22 See id § 577A, Comment on Subsection (1).

23 Only Montana has explicitly rejected the single publication rule and continues to use the older multiple publication rule. See Lewis v Reader's Digest Association, Inc, 162 Mont 401, 512 P2d 702, 705-06 (1973) (adopting the multiple publication rule out of concern that Montana residents would be forced to sue libelers in other states). The Wyoming Supreme Court has not yet explicitly rejected the single publication rule, but the Tenth Circuit has noted that it probably will. Anselmi v The Denver Post, Inc, 552 F2d 316, 325 (10th Cir 1977) (noting that "the single publication rule has not been adopted in Wyoming and is unlikely to be adopted"). Since both of these opinions are more than twenty years old, it is not clear whether these courts would continue to reject the single publication rule if faced with a libel case today.

24 Alaska, Arkansas, Delaware, Hawaii, Indiana, Kentucky, Maine, North Carolina, Oregon, South Dakota, Utah, West Virginia, and Wisconsin do not appear to have addressed this question. Kansas and Nevada have not formally adopted the single publication rule, but the federal district courts in those states have applied it. See, for example, Beech Aircraft Corp v National Aviation Underwriters, 1984 US Dist LEXIS 24862, *60 (D Kan) ("While no Kansas state court has ever formally adopted the single publication rule, several federal courts have predicted that it would."); Flowers v Carville, 112 F Supp 2d 1202, 1210 (D Nev 2000) (noting that most states have adopted the single publication rule and finding it applicable).

25 States that have legislatively adopted the USPA are Arizona, California, Idaho, Illinois, New Mexico, North Dakota, and Pennsylvania. See Strick v Superior Court for the County of Los Angeles, 192 Cal Rptr 314, 319 n 3 (1983). Texas adopted the USPA judicially in Holloway v Butler, 662 SW2d 688, 690 (Tex App 1983) (following, inter alia, the rationale laid out in Gregoire, $298 \mathrm{NY} 119,81 \mathrm{NE} 2 \mathrm{~d} 45$ (1948) for abandoning the multiple publication rule in favor of the USPA).

26 Uniform Single Publication Act $1952 \S 1$ (West 2001). 
broadcast over radio or television or any one exhibition of a motion picture.

The rule set forth in the USPA is essentially indistinguishable from the Restatement formulation, and courts in USPA states have generally found that the single publication rule only applies to mass publications. ${ }^{2 B}$ This Comment will therefore treat caselaw from Restatement states as being relevant to USPA states, and vice-versa.

The single publication rule protects defendants and courts from the large number of suits that would result if each person who read a libelous statement (or saw/heard a libelous broadcast or exhibition) could provide the basis for a new cause of action. ${ }^{29}$ The rule is also needed to give effect to the statute of limitations. ${ }^{30}$ The alternative rule would reset the statute of limitations every time a third party saw the libelous statement, regardless of how many years had passed since the libelous statement was published. ${ }^{31}$

The date of "publication" varies widely from state to state..$^{32}$ In the interest of setting up a framework with which to analyze website libel,

27 Id.

28 Though the USPA does not explicitly require that the libelous statement be made by mass or aggregate communication for the single publication rule to apply, most courts that have considered the issue do. See Baugh v CBS, Inc, 828 F Supp 745, 756 (ND Cal 1993) ("The enactment of section 3425.3 of the Uniform Single Publication Act by the California Legislature reflected great deference to the First Amendment and sought to alleviate many problems presented in respect to tort actions where mass communications are involved."); Schneider v United Airlines, Inc, 256 Cal Rptr 71, 74 (1989) (holding that the USPA does not apply in credit report libel cases and noting that the USPA "provides there is only one publication in mass communications of a single article in a newspaper or book or magazine which is distributed to more than one person" and that the USPA "was designed to protect a publisher who prints numerous copies of libelous matter, which copies are then distributed over a substantial period of time") (quotations omitted). See also Wathan v Equitable Life Assurance Society of the United States, 636 F Supp 1530, 1536 (CD Ill 1986) (noting that the central purpose of the USPA is to protect those involved in the mass media, and that it therefore did not make sense to apply the USPA to a case involving the distribution of posters at a meeting that were later redistributed by one individual who was present at the meeting).

29 See Restatement (Second) of Torts $\$ 577 \mathrm{~A}$, Comment on Subsection (3).

30 See Gregoire, 81 NE2d at 47 (applying the single publication rule to book publishers to prevent the dilution of the statute of limitations).

31 See id at 48-49 (noting that, without the single publication rule, if a book containing libelous material is printed, "the Statute of Limitation would never expire so long as a copy of such book remained in stock and is made by the publisher the subject of a sale or inspection by the public").

32 See, for example, Mullin $v$ Washington Free Weekly, Inc, 785 A2d 296, 298 n 2 (DC App 2001) (holding that the statute of limitations runs from the date on which the mass publication is first generally available to the public); Poff $v$ Hayes, 763 So2d 234, 242 (Ala 2000) (holding that the date of publication is "the date on which the injury to the plaintiff's reputation occurs and the cause of action is completed"); Williamson v New Times, Inc, 980 SW2d 706, 710 (Tex App 1998) (holding publication is complete on "the last day of the mass distribution of copies of the printed matter"). 
this Comment will use New York and California caselaw as a basis for when publication occurs. ${ }^{33}$ In these states, publication occurs on the date that the libelous statement is distributed to the public. ${ }^{34} \mathrm{~A}$ statement is considered to be distributed to the public when the writing is communicated to a "meaningful mass" of readers for which the publication was intended. ${ }^{35}$ Thus, the statute of limitations does not begin to run until the victim has suffered harm. ${ }^{36}$

If, however, the statement is not made as part of a single edition, broadcast, or exhibition of the mass communication in question, then republication occurs, giving the victim a new cause of action. ${ }^{37}$ For example, suppose the same libelous statement is published in the morning and evening editions of a newspaper. Then the statement is considered to be republished in the later edition. In other words, each edition is a separate, individual publication and thus a separate cause of action. $^{38}$ Likewise, if a libelous book was originally released in hard-

33 New York has the most libel caselaw of all the states that follow the Restatement, and California has the most libel caselaw of all the states that follow the USPA. Furthermore, the courts in these two states tend to take the same approach to various libel issues.

34 See Firth $v$ New York, 706 NYS2d 835, 841 (Ct Cl 2000), affd 731 NYS2d 244 (App Div 2001), affd 98 NY2d 365, 775 NE2d 463 (2002) ("[P]ublication occurs when the defamatory work first becomes generally available to the public or is placed on sale"); Strick, 192 Cal Rptr at 317 ("Under the single publication rule, publication of an integrated issue of a mass media writing occurs upon the first general distribution of the material to the public.").

35 See, for example, Stockley v AT\&T Information Systems, Inc, 687 F Supp 764, 768 (ED NY 1988) (noting that the single publication rule is "designed to restrict the subject of an allegedly defamatory writing to a single cause of action that accrues when the writing is released to its intended audience"); Osmers v Parade Publications, Inc, 234 F Supp 924, 927 (SD NY 1964) ("[W]hat is really determinative is the earliest date on which the libel was substantially and effectively communicated to a meaningful mass of readers - the public for which the publication was intended, not some small segment of it"); Strick, 192 Cal Rptr at 317 (holding that publication occurs upon first general distribution of the libel to the public, with the determinative factor being "the earliest date on which the allegedly defamatory information is "substantially and effectively communicated to a meaningful mass of readers") (quotation marks omitted). See also Printron, Inc v McGraw-Hill, Inc, 35 F Supp 2d 1325, 1326 (D NM 1998) (quoting Osmers); Ratliff $v$ Farm Progress Companies, Inc, 1992 WL 240661, *3 (ED Ky) (holding that publication occurs when the libelous publication is "substantially and effectively communicated to a meaningful mass of readers").

36 See, for example, Osmers, 234 F Supp at 927 (noting a hypothetical scenario in which, if courts held that publication occurred at the time an offending publication is placed on sale, a publisher could shorten the statute of limitations by selling a few advance copies of a libelous magazine before later releasing it to the general public).

37 See Restatement (Second) of Torts $\S 577 \mathrm{~A}$ (noting that each of several communications to a third person by the same defamer is a separate publication, except for a single communication heard at the same time by two or more third persons or any one edition or broadcast of an aggregate communication, which are both single publications). See also Firth, 706 NYS2d at 84142 (noting that republication occurs when a defamatory article is placed in a new form or edited in a different manner); Rinaldi v Viking Penguin, Inc, 438 NYS2d 496, 420 NE2d 377, 381 (1981) (holding that a repetition of defamation in a later edition can still give rise to a new cause of action).

38 See Restatement (Second) of Torts $\$ 577 \mathrm{~A}$, cmt d. 
back and a year later is re-released in paperback, two publications have occurred. ${ }^{39}$

Republication is an important part of maintaining the balance between protecting libel victim and publisher interests. Though one of the major factors adopting the single publication rule was to avoid multiple causes of action, ${ }^{40}$ allowing for republication avoids giving publishers "unending immunity" for repeated publications of a libelous statement. ${ }^{41}$ Allowing for republication is also based on the idea that the single publication rule should give a single cause of action when a libelous statement reaches a particular audience. If the statement reaches a new audience, then republication should occur.

\section{Website Libel Caselaw}

Courts have only begun to look at how to apply the single publication rule to libel on the Web. In 1999, Arizona became the first state to extend the single publication rule to the Web in a little known case, Simon v Arizona Board of Regents. ${ }^{43}$ In Simon, a libelous statement first appeared on a newspaper's website on October 9, 1997, and then appeared the next day in the printed version of the same newspaper." The plaintiff filed suit on October 13,1998, four days after the statute of limitations had run on the website claim. ${ }^{45}$ But, because October 10, 1998 was a Saturday and October 12, 1998 was a holiday, the filing was

39 For a general discussion, see Rinaldi, 420 NE2d 377 (holding that the release of a paperback edition of a libelous book constitutes republication).

40 See notes 5 and 29 and accompanying text.

41 See Schneider $v$ United Airlines, Inc, 256 Cal Rptr 71, 75 (App 1989) (noting that the single publication rule was "not designed to give unending immunity for repeated publications of libelous matter").

42 See Nacinovich v Tullet \& Tokoyo Forex, Inc, 1998 WL 1050971, *9 (NY Super Ct) (holding that concern regarding the preservation of the statute of limitations is unwarranted in a case involving a non-mass media publication of libelous cartoons because "the only manner in which these cartoons could have been seen again after their alleged initial publication was for someone ... to have made a knowing and conscious effort to disseminate them to third persons," in which case the single publication rule would be inapplicable because of the willful act). See also Givens, $877 \mathrm{~F}$ Supp at 489 (holding that an article is republished if the defendant consciously and independently reaches a new audience); Summers $v$ The Washington Times, 1993 US Dist LEXIS $13095, * 4-5$ (D DC) (holding that a libeler may only face liability for republication if republication to a new audience was reasonably foreseeable); Davis, 580 F Supp at 1094 ("[A] deliberate decision to republish or active participation in implementing the republication resurrects the liability otherwise laid to rest by the statute of limitations."); Schneider, 256 Cal Rptr at 74-75 (holding that if a publication reaches a new group, the repetition justifies a new cause of action).

4328 Med L Rep 1240 (Ariz Super Ct 1999) (discussing a libel suit brought by a college athlete against a newspaper that published, on the internet and in print on the following day, a defamatory article about the athlete's academic performance in college).

44 Id at 1242.

45 Id. 
still timely if a republication had occurred on October 10,1997, when the print edition of the newspaper was first published. ${ }^{46}$

The court found that the single publication rule applies to website publications. Moreover, it found that the distribution of the same story in the print edition of the newspaper did not constitute republication. The statute of limitations therefore began to run on October 9, 1997, the day of publication on the newspaper's website. ${ }^{47}$ Thus, the libel claim was filed four days too late.

The court emphasized that the allegedly libelous article was available to the public from the time it was uploaded to the Web. The court noted that the article was available to "an unlimited number of internet users world-wide" and was accessed at least five times by Arizona computers. ${ }^{49}$ Thus, the article was available to both the general and Arizona public the evening it was uploaded.

Firth $v$ New York $k^{50}$ provides the most detailed analysis of website libel to date. The plaintiff sued more than a year after the libelous report was published on the Web, despite the fact that the statute of limitations for libel claims in New York is one year. The plaintiff argued that each day that the report was available upon the Web constituted a new publication, and thus the statute of limitations had not run. ${ }^{\text {st }}$ The Court of Claims found that the single publication rule applied to websites and that the claim was time-barred. ${ }^{52}$ The decision was upheld by both the Appellate Division of the New York Supreme Court and by the Court of Appeals of New York. ${ }^{53}$

Firth has proven to be a seminal case, providing the first thoughtful discussion as to why the single publication rule should apply to the Web. The Court of Appeals of New York noted that " $[t]$ he policies impelling the original adoption of the single publication rule support its application to the posting of the ... report regarding claimant on the

46 See Blaine Kimrey, Statute of Limitations for Newspaper Defendants Runs From Initial Internet Publication (Lathrop \& Gage LC), online at http://www.lathropgage.com/ pub_on_line_legal.html (visited Jan 29, 2003).

47 Simon, 28 Med L Rptr at 1245-46.

48 See id. Note that this case is highly unorthodox because generally when an article is published in two different editions of the same newspaper, there are two publications. See Restatement (Second) of Torts \$ 577A, cmt d.

49 Simon, 28 Med L Rptr at 1246.

50 706 NYS2d 835 (Ct Cl 2000), affd 731 NYS2d 244 (App Div 2001), affd 98 NY2d 365, 775 NE2d 463 (2002) (discussing for statute of limitations purposes whether the single publication rule is applicable to allegedly defamatory statements posted on an internet site and whether modification of an unrelated portion of the website constitutes republication).

51 Id at 841

52 See id at 843.

53 See Firth, 731 NYS2d at 247, affd 775 NE2d at 467 (upholding the ruling of the Court of Claims that the single publication rule applies to internet publications and modification of unrelated portions of a website does not constitute republication). 
...Web site. ${ }^{\text {"st }}$ It stated that a libel accessible on a website is similar to that contained in traditional mass media, but on a larger scale. ${ }^{\varsigma 5}$ The court noted that such libelous websites could be viewed "by thousands, if not millions," over large geographic areas and for an indefinite amount of time. ${ }^{36}$ The multiple publication rule would have an even greater potential for retriggering the statute of limitations than would print libel, and could lead to a "multiplicity of suits and harassment of defendants." Worrying that this would inhibit the open dissemination of information over the internet, the court held that the single publication rule applies.

Firth is also important because of New York's prominent role in the development of libel doctrine generally. Though not the first state to adopt the single publication rule, ${ }^{59}$ New York was its most influential advocate. The well-known decision in Gregoire v GP Putnam's Sons ${ }^{60}$ marked the start of a trend where New York repeatedly influenced the development of libel law in other states. ${ }^{61}$ Likewise, despite not being the first state to apply the single publication rule to the Web, Firth has attracted media attention ${ }^{62}$ and has given New York another opportunity to set the tone for libel doctrine throughout the country.

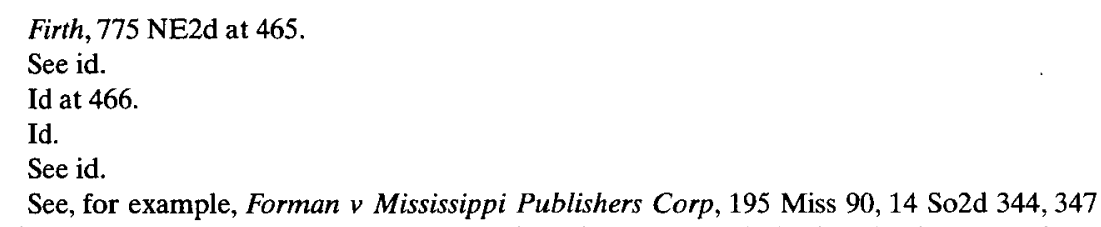
(1943) (holding that for a libelous newspaper article, the statute of limitations begins to run from the first date of publication).

60298 NY 119, 81 NE2d 45, 47 (1948) (applying the single publication rule to book publishers to prevent the dilution of the statute of limitations).

61 For an example of another state with a similar approach to New York libel doctrine, see Dale System, Inc v Time, Inc, 116 F Supp 527, 529 (D Conn 1953):

There has long been an affinity between the legal philosophies of the courts of New York and of Connecticut.... Although the Connecticut courts as yet have had no occasion to discuss and pass upon the 'single publication' rule which has been adopted in New York as recently restated in [Gregoire], the foregoing considerations, coupled with the general policy of the Connecticut courts to shape the law of the State to harmonize with the realities of contemporary life, convince me that a Connecticut court if confronted with this case would adopt the 'single publication rule.'

See also Holloway v Butler, 662 SW2d 688, 691 (Tex App 1983) (following the rationale laid out in Gregoire for abandoning the multiple publication rule); Barres $v$ Holt, Rinehart \& Winston, Inc, 131 NJ Super 371, 330 A2d 38, 43-45 (1974), affd 74 NJ 471, 378 A2d 1148 (1977) (citing in detail the Gregoire court's rationale for adopting the single publication rule); Rives $v$ Atlanta Newspapers, Inc, 110 Ga App 184, 138 SE2d 100, 103 (1964), revd 220 Ga 485, 139 SE2d 395 (1964) (following the Gregoire assessment that the English multiple publication rule was outdated).

62 See Carl S. Kaplan, Judge Says Old Rule on Libel Suits Applies Online, NY Times (Mar 31,2000), online at http://www.nytimes.com/library/tech/00/03/cyber/cyberlaw/31law.html (visited Jan 29, 2003). 
There are, however, several shortcomings in Firth. Despite the attention the New York courts paid to whether the single publication rule should apply to the Web, they did not carefully analyze what constitutes publication on the Web. The Court of Claims noted that publication occurs when a libelous article becomes available to the public. However, that court and the Appellate Division concluded without explanation that publication occurred as soon as the report was placed on the Web. ${ }^{64}$ The Court of Appeals merely noted the lower courts' decisions and did not discuss the issue further.

There were also deficiencies in the courts' discussions of the date of republication. The Court of Claims and Appellate Division both concluded without explanation that republication could not occur on the Web so long as the libelous statement in question was not altered in some way. ${ }^{66}$ In a dissent in the Appellate Division, two judges questioned the high standard that had been set for finding republication. While the dissent agreed that the single publication rule should apply to website libel cases, ${ }^{67}$ it raised the question of whether republication could occur without the report being modified. ${ }^{68}$

In contrast with the lower courts, the New York Court of Appeals did not take a firm stance against finding republication for an unmodified libelous statement on the Web. However, it found that the "addition of unrelated information to a Web site cannot be equated with the repetition of defamatory matter in a separately published edition of a book or newspaper." ${ }^{, 69}$

Shortly after the Court of Claims decision in Firth, the Southern District of New York decided Van Buskirk v New York Times. ${ }^{70}$ This unpublished case dealt with a defamatory letter that was published on the Web. The court noted that under the single publication rule, the statute of limitations does not begin to run again when the same material is subsequently distributed to new readers. ${ }^{\text {" }}$ Although the plaintiff argued that internet publishers should not be protected by the single publication rule because they can withdraw their material at any time, ${ }^{n}$ the court rejected this view. It noted that the New York Court of Appeals had found that if a publisher sold a libelous book from

\footnotetext{
63 See Firth, 706 NYS2d at 841.

64 See id at 843; Firth, 731 NYS2d at 247.

65 See Firth, 775 NE2d at 464.

66 See Firth, 706 NYS2d at 843; Firth, 731 NYS2d at 247.

67 See Firth, 731 NYS2d at 247 (Peters dissenting).

68 Id at 248 .

69 Firth, 775 NE2d at 466.

702000 US Dist LEXIS 12150 (SD NY) (unpublished).

71 See id at $* 4$.

72 See id at $* 6$.
} 
stock, it did not constitute republication. ${ }^{3}$ The court pointed out that the libelous statement in this situation could have been withdrawn as well, but that nevertheless, the single publication rule applied.

\section{INITIAL PUBLICATION AND REPUBLICATION ON THE WORLD WIDE WEB}

This Part first discusses the current approach of courts in determining when initial publication occurs on the Web. It argues that, under this approach, publication can occur before the libelous statement has an audience, unnecessarily shortening the victim's window of opportunity to sue. This Part next argues that the courts' consideration of republication on the Web is overly restrictive. Finally, it discusses how the courts' current approach can lead to abuse of the statute of limitations.

\section{A. Initial Publication on the World Wide Web}

The idea that publication on the Web and traditional print publishing are similar enough to merit application of the single publication rule is not controversial. The idea was suggested as early as $1996^{74}$ and few people have spoken out against the rule's expansion to the Web.

But, aside from a brief discussion in Simon, courts have overlooked the single publication rule's requirement that the libelous work be available to the public. ${ }^{76}$ Merely placing an article on the Web does not fulfill the requirement of public distribution because information exists on the Web that cannot be viewed by the general public. This can be due to "commercial strategies, peering disputes, network failures, misconfiguration, and occasionally, malicious intent." " Likewise, information may be viewable on the Web, but not listed in any

73 See id.

74 See Byron F. Marchant, On-line on the Internet: First Amendment and Intellectual Property Uncertainties in the On-line World, 39 Howard L J 477, 492 n 90 (1996) (noting that while no caselaw existed on internet defamation in 1996, analogous caselaw regarding the single publication rule should provide guidance).

75 The only published article that speaks out against using the single publication rule for website publications is Odelia Braun, Comment, Internet Publications and Defamation: Why the Single Publication Rule Should Not Apply, 32 Golden Gate U L Rev 325 (2002). Even in the dissent in Firth, Judge Peters was careful to emphasize that he agreed with the majority's "outright rejection of the continuing violation doctrine," to avoid having the statute of limitations reset each time a user accessed an online document. 731 NYS2d at 247.

76 See note 43 and accompanying text.

77 See Craig Labovitz, Abha Ahuja, and Michael Bailey, Shining Light on Dark Address Space 1 (Arbor Networks), online at http://research.arbornetworks.com/up_media/up_files/ dark_address_space.pdf (visited Jan 29, 2003). 
search engines, making it difficult to find. ${ }^{78}$ For instance, suppose Jones places a defamatory statement about Smith at the following fictitious URL: http://10.179.8.31/foo3455/ixworwa.html. ${ }^{79}$ Jones's website is not listed in any search engine and no other website links to it. ${ }^{80}$ Further suppose that Jones has not told anybody about the website, but intends for it to eventually have visitors. In other words, this is not a website that Jones intends to be private.

78 Other studies have shown that the amount of information locatable on the Web is less than the amount theoretically published on the Web. See Steve Lawrence and C. Lee Giles, Accessibility of Information on the Web, 400 Nature 107, 107-09 (July 8, 1999) (attempting to quantify the size of the publicly indexable web and comparing the coverage and recency of major search engines).

79 URL stands for Uniform Resource Locator. See T. Berners-Lee, L. Masinter, and M. McCahill, Request for Comment 1738 (Network Working Group 1994), online at http://www.ietf.org/rfc/rfc1738.txt (visited Jan 17, 2003). The RFC mechanism provides for commentary or (in this case) official standards published by the Internet Engineering Task Force (http://www.ietf.org). RFC 1738 defines a uniform and flexible way to address internet resources. Consider the URL http://www.cnn.com. The URL as a whole tells computer software how to get somewhere - in this case, the online location of CNN news. The prefix "http" refers to the Web protocol. See T. Berners-Lee, R. Fielding, and H. Frystyk, Request for Comment 1945 (Network Working Group 1996), online at http://www.ietf.org/rfc/rfc1945.txt (visited Jan 29, 2003). www.cnn.com refers to the host or computer with which to connect. To actually connect to this URL, a web-browser program must convert the hostname (www.cnn.com) into numerical format. See definition of DNS online at http://www.webopedia.com/TERM/D/DNS.html (visited Jan 29, 2003) ("Every time you use a domain name, therefore, a DNS service must translate the name into the corresponding IP address."). This process is similar to looking up a ZIP code from a street address. There is no requirement that a correlating name exist, so a website could instead use its numeric format, such as http://10.179.8.31. The remainder of the URL specifies how to find the specific item (ixworwa.html) on the host 10.179.8.31.

80 There are several uses for such a URL outside the context of trying to manipulate the statute of limitations for libel. A person may put up a personal website to which she wants only a few friends to have access. If the URL is not guessable and nobody links to the website, the website will remain completely private. Non-guessable URLs can also be used to share large amounts of data. For example, scanned photographs can take up a large amount of disk space. If a person wants to send photographs to a Hotmail user with only five megabytes of disk space, email may not be practical. That person may instead choose to put the photographs on her website and tell her friend the address. The friend can then download the photographs without email. In an online business context, non-guessable URLs can be used for email address verification. After a customer registers at a website, an email can be sent to the customer containing a unique URL. The email can ask the user to click on an URL to confirm her address. Because the website is unique, when the user clicks on it, the online business will know that the email address is valid.

81 Defamation (and thus libel) is an intentional tort, and publication thus occurs only when a libeler intentionally communicates libelous material to a third party. See note 11 and accompanying text. This Comment focuses on website publications that are intentional. There are interesting issues regarding where the line is drawn between an intentional and unintentional publication on a website. Suppose a website owner intends for a libelous website to be completely private, but the URL is discovered and made public. One could try to argue that requisite intent has been met for libel, given that the website was published on the Web and there was always a chance that the URL would be discovered.

An even harder line to draw is determining when a website publication is considered to be a mass publication under the single publication rule. If a libelous website is accessible only to registered users, how many users must be registered for the single publication rule to apply? Or is 
Jones's page is "public" in the sense that it is available to anyone who happens to guess its exact location. Yet it is highly unlikely that someone could, by chance, find Jones's page. Until the website is discovered, it is not conceptually different from a libelous book left on a seldomly perused bookshelf in a public library. As with the website, a possibility exists that someone will find and read the book. But given that the book is not indexed in any way and can only be found through luck, its contents have not been publicly distributed.

It seems absurd that Jones's placement of the statement in an obscure location provides Smith with a cause of action for libel. Defamation requires the defamer to communicate the defamatory statement to a third party. ${ }^{82}$ In Smith's case, there exists only a potential for harm, because nobody has discovered that the website exists. But under the approach in Firth, the mere presence of the statement on the Web is public enough to start the clock on the statute of limitations for Smith's libel claim. This is problematic because the necessary element that the libel be communicated to a third party is satisfied. In other words, Smith does not have a cause of action for libel at this time, because nobody has seen the website. But if the website does gain an audience in the future and reputational harm to Smith results, the statute of limitations will already be running, diminishing Smith's window of opportunity to sue. Furthermore, this "loophole" in the single publication rule could be exploited by libelers seeking to evade suit.

\section{B. Republication on the World Wide Web}

Under the Restatement and the USPA, republication occurs if the new publication is not part of the original edition, broadcast, or exhibition. ${ }^{84}$ For example, if a libelous statement is broadcast on a radio show and the entire show is later reaired, then there are two causes of action for libel, each with its own statute of limitation.

Yet courts have been reluctant to find that a libelous statement on a website is republished when the content of the statement is unchanged. The Court of Claims in Firth dismissed the idea, writing that, "Under the single publication rule, publication occurs at the time the defamatory article is made available to the public and actual sales of the article (the equivalent of "hits" on the internet) are unnecessary."

the limited-access website always mass communication, even if only five people are registered?

82 See note 10 and accompanying text.

83 See notes 89-96 and accompanying text.

84 Restatement (Second) of Torts $\$ 577 \mathrm{~A}, \mathrm{cmt} d$ (1977) (stating that the single publication rule does not include separate aggregate publications on different occasions).

85 See id.

86 Firth, 706 NYS2d at 841. The court does not define "hits." For a definition of "hits," see 
The court went on to hold that while the act of making a document available constitutes publication, "in the absence of some alteration or change in form its continued availability on the internet does not constitute a republication acting to begin the Statute of Limitations anew each day." ${ }^{, 87}$ Other courts have agreed. In Simon, the court even found that republication had not occurred when a libelous article that was initially published on the Web was reproduced in print. ${ }^{88}$ Consequently, no matter how obscure a website is, the single publication rule applies and republication will not occur regardless of significant changes in the size or character of website viewership.

These decisions could open the door to fraud. Courts are generally reluctant to grant injunctive relief to libel victims, and instead prefer to award damages after harm has occurred. ${ }^{89}$ Given that a libel victim cannot sue before significant harm occurs, the libeler could manipulate the statute of limitations to cause significant damage without facing liability. This problem was discussed more than thirty years ago by the Pennsylvania Supreme Court. The court held that a plaintiff could choose any publication as the single publication that represents her cause of action. ${ }^{.0}$ The Court's rationale for the rule was to avoid a potential for abuse by libelers." As an example, the Court stated that a publisher might print a defamatory article about a California resident and distribute a few copies in New York. The California resident might not feel an action was warranted given the small audience. After the statute of limitations had run, the publisher could then "flood California and the rest of the country with the article and ... face no threat of liability." Without the Pennsylvania rule, the libel victim, in theory, would have no recourse for the damages resulting from the California distribution.

For traditional libel, this fear of abuse is not warranted. Most courts would probably treat the distribution in California as a new publication, because the second distribution reached a new audience.

Robbin Zeff and Bradley Aronson, Advertising on the Internet 98 (John Wiley \& Sons 2d ed 1999).

87 Firth, 706 NYS2d at 843.

88 See note 43 and accompanying text.

89 See note 17 and accompanying text.

90 See Dominiak v National Enquirer, $439 \mathrm{~Pa} 222,266$ A2d 626, 629 (1970) (holding that the statute of limitations need not run from the time of the initial publication and that a "plaintiff may choose any publication as the single publication which represents his single cause of action").

See id.

92 Id.

93 See, for example, Bankers Trust v Weinick, Sanders \& Co, 1993 US Dist LEXIS 16076, *17 (SD NY) (holding that a deliberate decision to republish a libelous statement or active participation in implementing such republication resurrects liability even if the statute of limitations 
A court might also find that the date of distribution in California is when the statute of limitations begins to run because that is the date when the article was communicated to the California public, the relevant audience for which the publication was intended."

The Pennsylvania Supreme Court's fear of abuse is justified, however, in the case of website libel if no allowance for republication is made. Suppose Alice is a prominent attorney who knows a disgruntled former classmate named Bob. On February 1, 2001, Bob creates a website claiming that Alice cheated on the Bar exam ten years earlier. Bob tells his friends about the site, but the site is not visited often. The amount of harm to Alice's reputation may be too small at this time for Alice to sue for damages.

Once statute of limitations has run, Bob promotes the website, causing the number of visitors to skyrocket. The website becomes extremely damaging to Alice, given the larger audience now viewing the statement. But despite the dramatic change in viewership for Bob's site, Alice has lost her right to sue. This is the same situation feared by the Pennsylvania Supreme Court - a libeler can work around the statute of limitations by making a token distribution of the libelous statement, in this case by way of an obscure website.

The most significant reason to fear abuse in the case of website libel is a libeler's ability to change a website from a small-scale distribution to a large-scale one. If a publisher prints one thousand copies of a book containing a libelous statement, the size of the audience will be limited based on the number of books printed. To reach a larger audience, the book publisher would need to print more books, which would constitute republication. Conversely, a website publisher who publishes a libelous website does not face the same physical constraints on reaching broader audiences.

has run); Schneider v United Airlines, Inc, 256 Cal Rptr 71, 74-75 (1989) (holding that under the USPA, the single publication rule does not include separate aggregate publications on different occasions, because such publications reach a new audience).

94 See Osmers $v$ Parade Publications, Inc, 234 F Supp 924, 927 (SD NY 1964) (holding that what is determinative for when the statute of limitation begins to run is when the libel was "effectively communicated to a meaningful mass of readers - the public for which the publication was intended, not some small segment of it").

95 For example, Bob could submit his website to search engines, purchase banner ads on legal websites, or place ads for the website in the local paper.

96 With the exception that the website publisher may need additional resources, such as computer servers to support the increase in traffic to the website. 


\section{METHODS FOR DETERMINING THE DATES OF PUBLICATION AND REPUBLICATION}

This Part proposes that initial publication should be found to occur when the intended audience has an opportunity to discover the libelous statement. It will suggest direct and indirect methods for determining when this occurs, such as examining website traffic data and looking at website archives. This Part then suggests that courts find republication on the Web when the libelous statement in question is somehow altered. Furthermore, courts should find republication even when the content of the libelous statement has not changed, provided that the libeler disseminates the libel to a new audience. To determine when republication has occurred, courts can utilize website traffic data and examine changes to the website where the libelous statement was published.

\section{A. Initial Publication Should Occur When the Website Becomes Accessible to Its Intended Audience}

To establish when publication occurs on the Web, courts should determine when the intended audience had a realistic opportunity to discover the libelous statement. Defamation law was built around the idea that harm to the victim begins when the defamatory statement is communicated to one or more third parties, ${ }^{97}$ at which point publication has occurred. ${ }^{98}$ Thus, under general libel law, if someone makes a libelous statement and no one reads it, libel has not occurred."

The single publication rule varies slightly from general libel law in that the date of publication is not the date that the statement was read, but rather the date when the statement was communicated to a meaningful mass of the intended audience. ${ }^{100}$ The spirit of the rule, however, is the same as for general libel law-there must be an audience to read the libel to trigger the statute of limitations. It is easy for printed libel to generate an audience, by nature of it being placed for sale, mailed, or distributed in some manner. Even if it is not widely distributed or advertised, a person might stumble upon a new book at

97 See note 10 and accompanying text.

98 See note 14 and accompanying text.

99 See W. Page Keeton, ed, Prosser and Keeton on Torts $\S 113$ at 797-98 (West 5th ed 1994); Vogel v New York, 721 NYS 2d 901, 904 (Ct Cl 2000) ("But, it is not enough to show that Defendant disseminated the defamatory communication; it must also be shown that a third party read it or heard it"). Compare Palestri v Monogram Models, Inc, 875 F2d 66, 68 (3d Cir 1989) (holding that the statute of limitations for a defamatory letter does not begin to run until the letter is read, but noting that under New Jersey's single publication law, the statute of limitations begins to run when the libel is published, not when it is read).

100 See note 36. 
a bookstore or discover a free magazine at a street corner newsrack. But unless the website publisher tells other people about the website, or the website has an URL that someone discovers, the work is not available to its intended audience in any meaningful way. ${ }^{10}$

In most cases, a libelous statement reaches its intended audience when it is posted to the Web. If a libelous statement is placed on a website with an existing audience, the intended audience would be the viewers of the main website and the statement being uploaded to the website would constitute distribution to that audience.

For websites without an existing audience, ${ }^{103}$ it is more difficult to determine when a libelous statement is sufficiently communicated for publication to occur. However, courts have overlooked several tools they can use to determine when a website has been published for purposes of a libel suit.

\section{Using traffic data to determine when publication occurs.}

The easiest way to determine when a website has reached a substantial mass of its intended audience is to look at website traffic data (if such information is kept by the website or the website's host). ${ }^{104}$ Traffic data comes in a variety of forms. A site may maintain statistical summaries of the number of hits or page views ${ }^{105}$ per minute, hour, and/or day. Alternatively, a website may maintain full logs of every instance in which the website server is accessed. This may contain the numerical IP address of each visitor, the time and date that they visited, and a list of pages on the site that they visited. These logs may also contain the sites from which a visitor was referred in the event

101 In the later case, the website publisher would also have to intend for the website to be public. See note 81 .

102 The court in Simon recognized this when it noted that an article published on a newspaper's website was immediately available to "virtually an unlimited number of Internet users." 28 Med L Rptr at 1246 (discussing a libel suit brought by a college athlete against a newspaper that published, on the internet and in print on the following day, a defamatory article about the athlete's academic performance in college).

103 Note that the obscure website could be located off a major site. For example, if an article was placed at http://www.nytimes.com/random/misc.html, and was not linked to the main site, this could constitute an obscure website as viewers of the main site would have no means by which to discover the article.

104 Many websites are hosted by third parties, so-called bulk-hosting companies. For a general description of the number of websites hosted by the largest bulk hosting services, see Netcraft Web Server Survey, (December 2001), online at http://www.netcraft.com/Survey/index200112.html (visited Jan 29,2003). Since large or heavily visited websites require more resources than smaller or less-frequently visited websites, these companies generally keep some type of usage information, if only for billing purposes. See generally Anne M. Burris, Service Provider Strategy: Proven Secrets for xSPs (Prentice Hall 2002) (discussing the business practices common to fifteen of the world's leading internet service providers).

105 See Zeff and Aronson, Advertising on the Internet at 100 (cited in note 86). 
that she followed a link to the site, as opposed to typing in the URL herself. ${ }^{106}$

\section{Indirect means of determining when publication occurs.}

There are several indirect means of determining when initial publication of a website occurs. A court could examine when advertising for the site began, when the site became listed on a major search engine, or when the site was linked to from a visited website. Any of these situations would indicate that viewers had an opportunity to discover the libelous statement.

Another useful tool that courts could use is an archiving site such as The Internet Archive. ${ }^{107}$ This website permits web users to view a page as it existed at various times in the past. An archival site may have a record of the libelous website, including the date when it was first discovered by their system for archiving. Since such archives contain only websites that are linked to other websites that the archive knows, ${ }^{108}$ this would establish an upper bound for the date of publication.

\section{B. Republication on the World Wide Web}

In addition to allowing libelers effectively to use the statute of limitations to prevent suits by taking an overly restrictive view of the date of publication, ${ }^{110}$ courts have opened the door to fraud by finding that a libelous statement on the Web must be altered in some way to be considered republished. ${ }^{111}$ To avoid this problem, courts should find that republication occurs if a website publisher knowingly disseminates a libelous statement to a new audience.

The single publication rule has never protected libelers who deliberately distribute a previously published statement material to a new audience. ${ }^{12}$ For example, in Stella $v$ Farley Association, Inc, ${ }^{113}$ a po-

106 Id at 96-97. Referring to website information is useful in determining whether the public had an opportunity to learn about the existence of the libelous site. It is also useful in determining whether banner ads exist for the libelous site.

107 The Internet Archive is located at http://www.archive.org.

108 See About These Collections, online at http:/www.archive.org/about/faqs.php (visited Jan 29, 2003).

109 It would only give the upper range for the date of publication because the archival site may have missed the libelous website before, even if the site was public.

110 See text accompanying notes $47-48$.

111 See text accompanying note 87.

112 See Nacinovich $v$ Tullet \& Tokoyo Forex, Inc, 1998 WL 1050971, *9 (NY Super Ct) (holding that concern regarding the preservation of the statute of limitations is unwarranted in a case involving the non-mass-media publication of libelous cartoons because "the only manner in which these cartoons could have been seen again after their alleged initial publication was for 
litical newsletter was created to aid a candidate's campaign. ${ }^{114}$ On August 17, several hundred copies of the newsletter were distributed to voters in the district by hand. ${ }^{115}$ At least fifteen thousand additional copies were mailed to voters, reaching them around August $20 .{ }^{116}$ The defendants argued that the date of publication was August 17, thus rendering several libel claims against them untimely. ${ }^{117}$ The court disagreed, holding that the date of publication of a newsletter "is not the date that a small percentage of the issue is distributed to readers, but rather the date when the great mass of the issue reaches those for whom the publication is intended." ${ }^{, 18}$ Accordingly, the court found that two separate distributions had occurred, one by hand and one by mail.

The logic of Stella should apply in cases where the publisher of a libelous website deliberately reaches a new audience. If a website initially attracts a small audience, but the size of the audience later increases, courts should investigate the intent of the publisher and find that republication occurred if the new distribution was intentional. One obvious case where republication could be found is if the publisher implements new means of advertising."

Starting an advertising campaign or greatly increasing spending on ads are conscious decisions intended to attract new viewers. However, absent such proof, there are two other factors that courts should consider. First, courts should look for major increases in traffic to the

\footnotetext{
someone ... to have made a knowing and conscious effort to disseminate them to third persons," in which case the single publication rule would be inapplicable because of the willful act). See also Givens v Quinn, 877 F Supp 485, 489 (WD Mo 1994) (holding that an article is republished if the defendant consciously and independently reaches a new audience); Davis v Costa-Gavras, 580 F Supp 1082, 1094 (SD NY 1984) ("[A] deliberate decision to republish or active participation in implementing the republication resurrects the liability otherwise laid to rest by the statute of limitations."); Schneider v United Airlines, Inc, 256 Cal Rptr 71, 74-75 (1989) (holding that if a publication reaches a new group, the repetition justifies a new cause of action). But see Summers $\checkmark$ The Washington Times, 1993 US Dist LEXIS 13095, *4-5 (D DC) (holding that a libeler may only face liability for republication if republication to a new audience was reasonably foreseeable).

113122 NYS2d 322 (Super Ct 1953), affd 135 NYS2d 234 (App Div 1954).

114 See id at 327

115 Id at 330.

116 Id.

117 See id.

118 Id.

119 A website wishing to attract more visitors may pay for various forms of advertising. One of the most common of these are "banner ads." The party desiring traffic may pay the operator of another website or a third party who acts as in intermediary to place links (often with images, etc.) to the website desiring more visitors. Since this advertising is often keyed to the number of visitors who view the advertisement or "click through" to the target website, detailed information may be available from this source. See Zeff and Aronson, Advertising on the Internet at 1-2, $11-19$ (cited in note 86 ).
} 
website. Second, they should look at whether the content surrounding the libelous statement has changed.

1. Changes in traffic.

When determining whether a libeler has attempted to reach a new audience, courts should consider whether the traffic to the website has increased substantially. ${ }^{120}$ Significant increases in traffic are pertinent because a distribution to the public occurs when the libelous material is "substantially and effectively communicated to a meaningful mass of readers." "If viewership of a website has historically been very low and suddenly increases by several orders of magnitude, the date of the sudden increase is the point at which the writing was truly "released" to its intended audience. In addition to signifying when a mass of readers has been reached, an increase in traffic could signal that the website owner was deliberately trying to reach a new audience through advertising or promoting the site on other websites, online bulletin boards, or other means.

While it is clear that republication occurs when the defendant has actively promoted the website, it is unclear whether republication occurs when an outside party hyperlinks to a defamatory website, allowing a new audience to view its content. For instance, Slashdot, a popular website, publishes user-submitted articles read by hundreds of thousands of viewers each day. ${ }^{122}$ When an interesting link is published in an article on Slashdot, thousands of new viewers may visit a previously obscure or even unpublished website, giving the linked website a vast new audience. ${ }^{123}$ This phenomenon, known as the "Slashdot Effect," has been observed when other major websites link to a previously obscure site. ${ }^{124}$ No analogy to this situation exists for print libel because the number of viewers of the libelous material is limited to the number of copies the publisher makes available.

There are three possible ways to respond to this situation. The first is to find that republication has not occurred even though the ar-

120 Such data is available because websites collect it themselves. See note 104 and accompanying text.

121 Osmers v Parade Publications, Inc, 234 F Supp 924, 927 (SD NY 1964). See also Strick v Superior Court for the County of Los Angeles, 192 Cal Rptr 314, 317 (1983) (interpreting Osmers to hold that the determinative factor in deciding when the first general distribution of defamatory information to the public occurs is when the information is communicated to a meaningful mass of readers).

122 See http://slashdot.org.

123 See, for example, Stephen Alder, The Slashdot Effect, An Analysis of Three Internet Publications, 38 Linux Gazette, online at http://www.linuxgazette.com/issue38/adler1.html (visited Jan 29, 2003).

124 See id. 
ticle has a new audience. A second possibility is to extend liability to the website that knowingly links to the libelous website. There are no examples of this happening in the context of defamation, but injunctions have been granted to websites linking to sites that violate the Digital Millennium Copyright Act ("DMCA"). In Universal City Studios, Inc $v$ Reimerdes, ${ }^{125}$ the Southern District of New York forced www.2600.com, the online version of 2600 Magazine, to remove links to websites offering DeCSS software, because the software was held to violate the DMCA. ${ }^{126}$ This act, however, raises substantial First Amendment concerns regarding the right to report news. ${ }^{127}$

The third possibility is to have a strict liability standard for the owner of the defamatory site who knowingly publishes defamatory material. Thus, the website owner could be held liable for a second cause of action due to an outside party's hyperlink, merely for having made the material public. These three methods of liability should be further examined to determine which would best serve the interests of the parties involved in website libel cases.

\section{Changes to the website.}

Courts should also consider whether changes to the website have been made. If the libelous article or report that appears on the website is altered, the court should find that it has been republished. ${ }^{128}$ The single publication rule only applies to a single libelous communication made in the aggregate. ${ }^{129}$ Thus, if changes are made to the libelous statement, republication must occur. This view is consistent with Firth, in which the court found republication could occur only if the defamatory report was modified.

Even if the libelous statement itself is unaltered, changes in other parts of the website should sometimes merit a finding of republication.

12582 F Supp 2d 211 (SD NY 2000).

126 Id at 227. DeCSS is software that breaks the copy protection on DVDs. See id at 214 . It thus allows users to play DVDs on their computers while running operating systems such as Linux that do not come with DVD-playing software. See Mike Snider, Free Speech Will Be Focus of DVD Battle, USA Today 3D (Apr 30, 2001).

127 See Snider, Free Speech (cited in note 126) (noting that the Electronic Frontier Foundation filed an appeal over the court's failure to grant 2600 First Amendment protection for its news coverage). See also Rob Pegoraro, Hollywood to Home Viewer: We Own You, Wash Post E01 (Aug 25, 2000) (noting the futility of banning links to illicit content under the DMCA).

128 This idea is also illustrated in the case Rinaldiv Viking Penguin, Inc, 438 NYS2d 496, 420 NE2d 377 (1981). In this case, the court found that the release of a libelous book into paperback form constituted republication. The court emphasized that the paperback edition was different from the original hardback edition because the phrase "Published in Penguin Books 1978" was added to the copyright page of the former. See id at 382 .

129 See Restatement (Second) of Torts $\$ 577 \mathrm{~A}, \mathrm{cmt}$ d.

130 See text accompanying notes $66-68$. 
This idea was first raised in the Appellate Division dissent in Firth. ${ }^{131}$ The dissent notes that after the libelous report was placed on the internet, modifications were made to the website from which the report could be accessed. ${ }^{132}$ It argues that the summary judgment proceeding left unresolved whether such modifications could support a finding that there was "a deliberate decision to republish or that there was active participation in implementing the republication," which would serve as a new cause of action. ${ }^{133}$

The Court of Appeals found that the addition of unrelated information to a website could not be equated with republication in the context of print libel..$^{134}$ The court, however, did not address the possibility that such changes could be considered as part of a comprehensive examination into whether the libeler was attempting to reach a new audience.

It also failed to distinguish between two types of unrelated information. The first type is information added to a website that is unrelated to the libelous statement. For example, if the operator of a newspaper website publishes a libelous article on the site and then posts a new newsworthy article, the newsworthy article would be of the type of content that would ordinarily appear on the website. Absent evidence that the publisher was attempting to reach a new audience, courts should not find that the libelous statement has been republished. The new content appeals to the same audience that the website as a whole does, thus making it unlikely that the libelous statement reached a new audience. This solution also prevents the problem that the Court of Appeals feared-that publishers would be forced to update websites less frequently out of fear of republication. ${ }^{135}$

The second type of unrelated information is information added to a website that is unrelated to both the libelous statement and the website's regular content. For example, if the newspaper website published a libelous article and then a week later repositioned itself as an online political message board, the unrelated content would likely bring the libelous statement a new audience. Such cases should warrant republication, because the new content draws a new audience to the website, and thus, to the libelous statement.

\footnotetext{
131731 NYS2d at 247-48 (Peters dissenting).

132 Id at 247.

133 Id at 248.

134 Firth, 775 NE2d at 466.

135 See id at 467.
} 


\section{CONCLUSION}

The current approach taken by courts applying the single publication rule to website libel cases inadequately protects the libel victim. In order to fulfill the goals of libel law, courts should find initial publication for website libel only when the website is truly available to the public. Furthermore, courts should find that a libelous statement on the Web has been "republished," if a website publisher knowingly disseminates the statement to a new audience. Republication should be possible even if the statement is unaltered. Such an approach would harmonize website libel doctrine with traditional libel law by incorporating from traditional libel the guidelines detailing when a publication is considered to be distributed to the public and when republication should occur. It would further prevent the statute of limitations from running on a website libel claim before the victim has a reasonable chance to discover the statement and would therefore prevent libelers from abusing the single publication rule to avoid liability. 